\title{
DISTRIBUTION OF CONGENITAL HEART DISEASES AT TERTIARY CARE CENTER: SINGLE CENTER EXPERIENCE
}

\author{
Vaishali Bhalavi ${ }^{1}$, Rajeev Gupta ${ }^{2}$
}

${ }_{1}^{1}$ Senior Resident, Department of General Medicine, Gandhi Medical College, Bhopal.

${ }^{2}$ Associate Professor, Department of Cardiology, Gandhi Medical College Bhopal.

ABSTRACT
BACKGROUND
The current study was undertaken at a tertiary care center, Bhopal, MP, India, with the objective of establishing frequency of
occurrence of congenital heart diseases by echocardiography.

\section{MATERIALS AND METHOD}

10,000 consecutive cases undergoing Echo Color Doppler in the Cardiology Department Hamidia Hospital, Bhopal, between $1^{\text {st }}$ Jan 2009 and July 2011 were analysed. Echo CD was performed by consultant cardiologist using Acuson Aspen Color Doppler machine following the ASE guidelines.

\section{RESULTS AND CONCLUSIONS}

In the present study out of 10,000consecutive cases undergoing echo 648 were identified to having congenital heart diseases. Isolated VSD (30.5\%), isolated ASD (23.6\%) PDA (9\%) and TOF (8.3\%) were commonest defect observed. Most common congenital heart disease found in the present study is VSD and is most prevalent in males and is highest among $0-5 \mathrm{yrs}$.

\section{KEYWORDS}

Congenital Heart Disease, Echocardiography, Occurrence of CHD, Central India.

HOW TO CITE THIS ARTICLE: Bhalavi V, Gupta R. Distribution of congenital heart diseases at tertiary care center: single center experience. J. Evolution Med. Dent. Sci. 2016;5(17):842-845, DOI: 10.14260/jemds/2016/195

\section{INTRODUCTION}

Congenital cardiovascular diseases are defined as an abnormality in cardiovascular structure or function that is present at birth. Cardiac malformation present at birth is an important constituent of paediatrics cardiovascular diseases and consists of major percentage of clinically significant birth defect with estimated prevalence $4-50 \%$ per 1000 live birth. It is estimated $4-10 \%$ live births have congenital malformations and $40 \%$ diagnosed in the first year of the life. ${ }^{1}$ To detect as many children with congenital heart disease as possible, including those with mild lesions, very intensive studies are required which may not be available at all hospitals. 2-dimensional echocardiography has revolutionized the diagnosis and management of cardiac malformations. It is a non-invasive investigation that can precisely diagnose most congenital heart diseases as well as offer treatment options, whether medical or surgical.

\section{MATERIALS AND METHOD}

The present study was conducted in cardiology department, Hamidia hospital, Bhopal, MP, Central India. The study period was January 2009 to July 2011.It was a retrospective study in which ten thousand consecutive cases of who were presenting to cardiology department either in ICCU and out-patient department undergoing echocardiographic examination were analysed. Data collected from echocardiography records, computerised and analysed.

Financial or Other, Competing Interest: None.

Submission 12-01-2016, Peer Review 10-02-2016,

Acceptance 16-02-2016, Published 27-02-2016.

Corresponding Author:

Vaishali Bhalavi,

B-3/76, Sahara States, Bhojpur Road,

Bhopal.

E-mail: dr.vaishalibhalavi@gmail.com

DOI: $10.14260 /$ jemds/2016/195
Echocardiography performed by Consultant Cardiologists using Acuson Aspen colour Doppler machine following the ASE guidelines. ${ }^{2}$

1. Conditions for which there is evidence or general agreement that a given procedure is useful and effective.

2. Conditions for which there is conflicting evidence and/or divergence of opinion in favour of usefulness/efficacy of a procedure. 2a: Weight of evidence/opinion is in favour of usefulness/efficacy. 2b: Usefulness/efficacy is less well established by evidence/opinion.

3. Conditions for which there is evidence and general agreement that the procedure is not useful/effective and in some cases may be harmful.

All the echocardiographic examination were recorded in supine and left lateral position taking all four views, i.e. parasternal long axis view, parasternal short axis view, apical four chamber view and apical two chamber views.

\section{RESULTS}

In the present study congenital heart disease was detected in 648 cases out of 10,000 consecutive cases undergoing echo. There were 337 males and 311 females with male-to-female ratio is 1.1:1.0. Table 1 and Figure 1 shows the age and gender wise distribution of congenital heart diseases in Central India.

\begin{tabular}{|c|c|c|c|c|}
\hline & & & NUMBER & $\%$ \\
\hline \multirow[t]{2}{*}{1} & SEX & MALE & 337 & 52 \\
\hline & & FEMALE & 311 & 47.9 \\
\hline \multirow[t]{8}{*}{2} & AGE & & & \\
\hline & & 0-5 yrs. & 358 & 55.2 \\
\hline & & 6-10 yrs. & 68 & 10.5 \\
\hline & & $11-15$ yrs. & 65 & 10 \\
\hline & & $16-30$ yrs. & 106 & 16.3 \\
\hline & & 31-45 yrs. & 30 & 4.6 \\
\hline & & $45-60$ yrs. & 21 & 3.2 \\
\hline & & $60 \&$ more & 0 & 0 \\
\hline
\end{tabular}




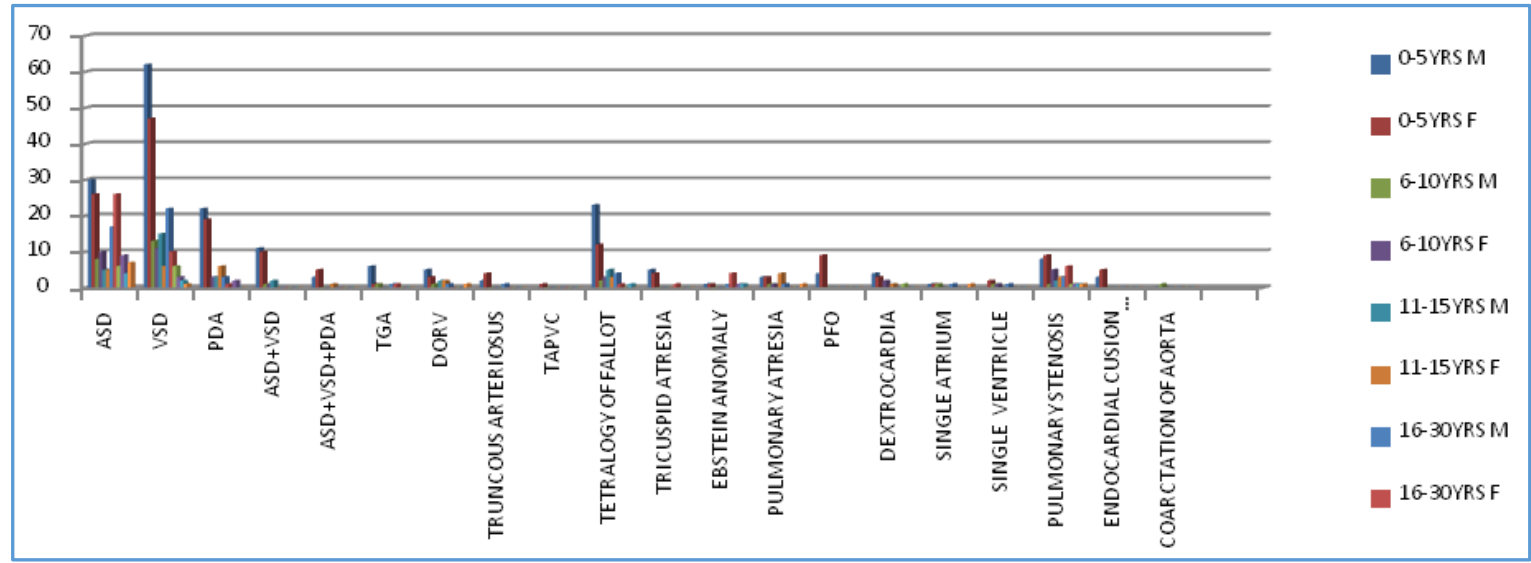

Fig. 1: Shows Age-wise and Gender-wise Distribution of Various Congenital Heart Diseases

Most common age affected in the present study is 0 -5yrs and predominantly affected males. Distribution of various congenital heart diseases in the study (Table 2). There were 444 (68.5\%) cases of acyanotic CHD, 120 cases (18.5\%) cyanotic CHD and 84 (12.9\%) rare CHD found in the present study.

\begin{tabular}{|c|c|c|c|c|c|}
\hline & & TOTAL & PERCENTAGE & MALE & FEMALE \\
\hline \multicolumn{6}{|l|}{ ACYANOTIC CHD } \\
\hline & ASD & 153 & 23.6 & 45.75 & 54.2 \\
\hline & VSD & 198 & 30.5 & 60.6 & 39.4 \\
\hline & PDA & 59 & 9 & 47.45 & 8.3 \\
\hline & ASD WITH VSD & 25 & 3.8 & 56 & 44 \\
\hline & ASD WITH VSD WITH PDA & 9 & 1.3 & 33.3 & 66.6 \\
\hline \multicolumn{6}{|l|}{ CYANOTIC CHD } \\
\hline & TGA & 10 & 1.5 & 80 & 20 \\
\hline & DORV & 15 & 2.3 & 60 & 40 \\
\hline & TRUNCUS ARTERIOSUS & 7 & 1.08 & 42.8 & 57.1 \\
\hline & TAPVC & 1 & 0.15 & & 100 \\
\hline & TOF & 54 & 8.3 & 64.8 & 35.2 \\
\hline & TRICUSPID ATRESIA & 10 & 1.5 & 50 & 50 \\
\hline & EBSTEIN ANOMALY & 9 & 1.38 & 33.3 & 66.67 \\
\hline & PULMONARY STENOSIS & 55 & 8.5 & 38.1 & 61.8 \\
\hline \multicolumn{6}{|l|}{ RARE } \\
\hline & PFO & 13 & 2.0 & 30.5 & 69.2 \\
\hline & DEXTROCARDIA & 11 & 1.7 & 45.5 & 54.5 \\
\hline & SINGLE ATRIUM & 5 & 0.7 & 60 & 40 \\
\hline & SINGLE VENTRICLE & 5 & 0.7 & 40 & 60 \\
\hline & ENDOCARDIAL CUSHION DEFECT & 8 & 1.23 & 37.5 & 62.5 \\
\hline & $\mathrm{COA}$ & 1 & 0.15 & 100 & 0 \\
\hline
\end{tabular}

VSD is the most common CHD found the present study followed by ASD, PDA and TOF and PS. Figure 2 and 3 shows acyanotic, cyanotic and rare congenital heart diseases in the present study.

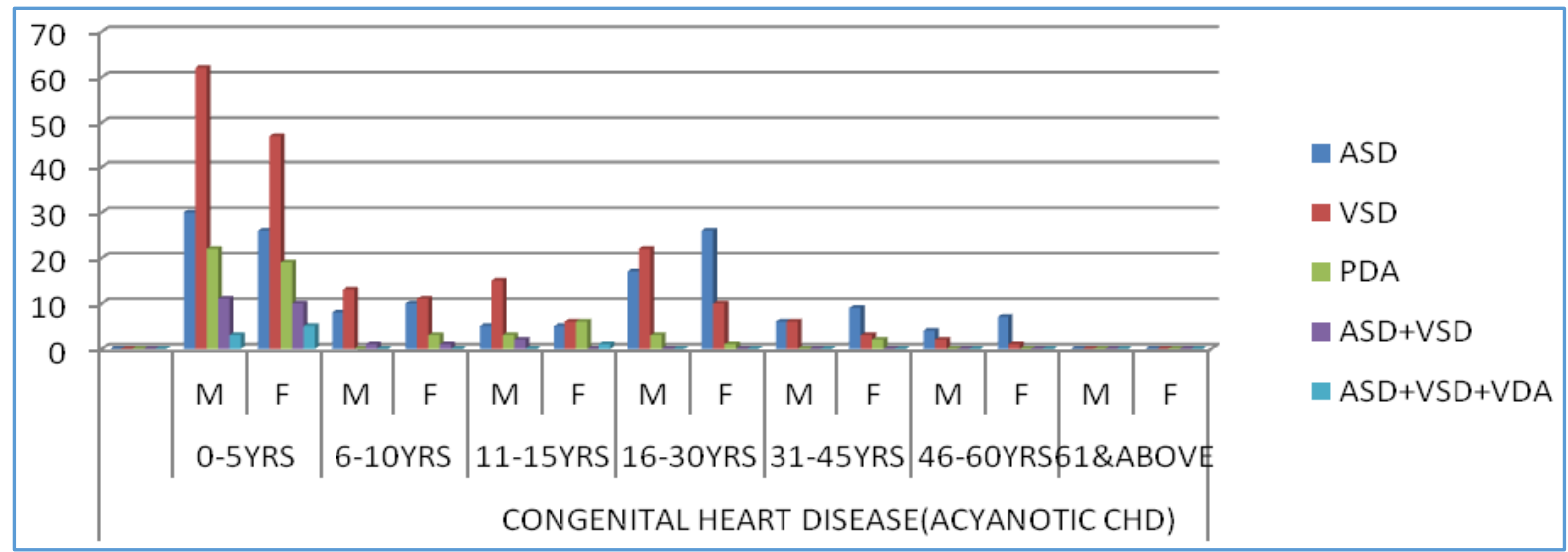

Fig. 2: Shows Acyanotic Congenital Heart Diseases in the Present Study 


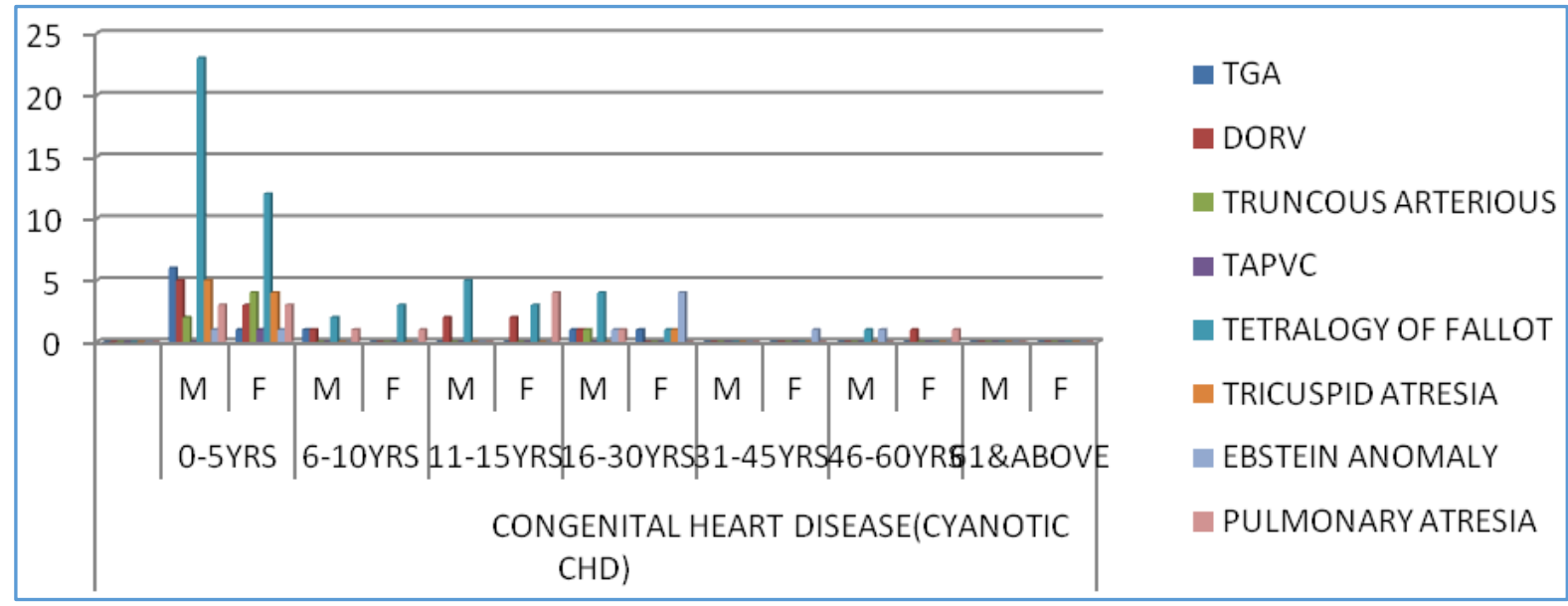

Fig. 3: Shows Cyanotic Congenital Heart Diseases in the Present Study

\section{DISCUSSION}

CHD has become an important cause of morbidity and mortality in infancy and accounts for two thirds of all major birth defects along with neural tube defects. The true incidence of congenial cardiovascular malformations is difficult to determine accurately. The reported incidence of CHD is 8-10/1000 live births according to different series of world. ${ }^{3}$ It is believed that the incidence has remained constant worldwide. ${ }^{4}$

In the present study of 10,000 consecutive cases undergoing echo 648 cases were diagnosed to have congenital heart diseases. Our studies show a male preponderance, which is in accordance with other studies by Chadha et al., Bidwai et al. and Jain et al.5,6,7

The most frequent type of congenital heart diseases was found to be VSD, which is in accordance with other studies by Chadha et al., Bidwai et al., Vashista et al. ${ }^{8}$, Sharma et al. ${ }^{9}$, Andreg Robid et al. ${ }^{10}$ Shreshta et al.11

When considering age at presentation we found that maximum number of cases affected in paediatric age groups (0-15 yrs.) in the present study is $4.91 \%$ which is similar to study by Chadha et al. as compared with other studies where incidence range from $0.27 \%-2.6 \%$ as shown in the table. ${ }^{5,8,11,12,13}$

\begin{tabular}{|c|c|c|c|c|}
\hline AUTHORS & $\begin{array}{c}\text { AGE- } \\
\text { GROUPS }\end{array}$ & $\begin{array}{c}\text { NO. } \\
\text { OF } \\
\text { CHD }\end{array}$ & TOTAL & PERCENTAGE \\
\hline Our study & $0-15 y \mathrm{ys}$ & 491 & 10,000 & 4.91 \\
\hline $\begin{array}{c}\text { Shreshta } \\
\text { et al. }\end{array}$ & $5-16 \mathrm{yrs}$ & 111 & 34,198 & 0.32 \\
\hline $\begin{array}{c}\text { Gupta } \\
\text { et al. }\end{array}$ & $6-16 \mathrm{yrs}$ & 270 & 10,264 & 2.6 \\
\hline $\begin{array}{c}\text { Vashishta } \\
\text { et al. }\end{array}$ & $5-15 \mathrm{yrs}$ & 44 & 8449 & 0.52 \\
\hline $\begin{array}{c}\text { Thakur } \\
\text { et al. }\end{array}$ & $5-16 \mathrm{yrs}$ & 30 & 10,964 & 0.27 \\
\hline $\begin{array}{c}\text { Chadha } \\
\text { et al. }\end{array}$ & $<15 \mathrm{yrs}$ & 574 & 11,833 & 4.58 \\
\hline \multicolumn{5}{|c|}{ Table 3: Comparison of Incidence } \\
of Congenital Heart Disease \\
\hline
\end{tabular}

Our study had 444 cases of acyanotic congenital heart disease, accounting $68.5 \%$ of cases and 120 cases of cyanotic congenital heart disease, i.e. $18.5 \%$. The preponderance of acyanotic congenital heart disease is in concordance with the results of other Indian studies (Kasturi et al., Bidwai et al., Shreshta et al.). In the present study, five most common CHD were $\mathrm{VSD}>\mathrm{ASD}>\mathrm{PDA}>\mathrm{TOF}>\mathrm{PS}$ and with compare with other studies as shown in Table 4.6,7,8,9,11,13,14,15,16.

\begin{tabular}{|c|c|c|c|c|c|c|c|c|c|c|}
\hline $\begin{array}{l}\text { CHD } \\
(\%)\end{array}$ & $\begin{array}{l}\text { Our } \\
\text { study }\end{array}$ & $\begin{array}{l}\text { Kasturi } \\
\text { et al. }\end{array}$ & $\begin{array}{c}\text { Jain } \\
\text { KK et } \\
\text { al. }\end{array}$ & $\begin{array}{c}\text { Bidwai } \\
\text { et al. }\end{array}$ & $\begin{array}{c}\text { Shreshta } \\
\text { et al. }\end{array}$ & $\begin{array}{c}\text { Kinare } \\
\text { et al. }\end{array}$ & $\begin{array}{c}\text { Vashishta } \\
\text { et al. }\end{array}$ & $\begin{array}{c}\text { Thakur } \\
\text { et al. }\end{array}$ & $\begin{array}{c}\text { Sharma } \\
\text { et al. }\end{array}$ & $\begin{array}{c}\text { Khalil } \\
\text { et al. }\end{array}$ \\
\hline VSD & 30.5 & 27.1 & 45.4 & 24 & 30 & 4 & 41 & 32 & 53 & 34.8 \\
\hline ASD & 23.6 & 24 & 3.6 & 21.96 & 23 & - & 11 & 38 & 13 & 2.3 \\
\hline PDA & 9.1 & 6 & 5.4 & 10.3 & 11 & 9 & 4 & - & 13 & 18.6 \\
\hline TOF & 8.3 & 9 & 18.6 & 25.4 & 4 & 12 & 14 & - & 32 & 4.6 \\
\hline PS & 6.3 & 8 & 5.4 & 2.9 & & - & - & - & 6 & \\
\hline & & & & & & & & & & \\
\hline \multicolumn{11}{|c|}{ able 4: Comparison of Congenital Heart Disease } \\
\hline
\end{tabular}

VSD was the commonest congenital heart disease seen in our study $(30.5 \%)$, which is similar to other Indian studies.7,8,9,11,14,16.

ASD was the second commonest congenital heart disease seen in $23.6 \%$ with other Indian studies. ${ }^{11,14}$ recording an incidence from 3.6-24\%. PDA accounts $9.1 \%$ in our studies, which is nearly similar to studies by Kinare et al. and Bidwai et al. and compare with other studies range from $4-13 \%$.
TOF was found in $8.3 \%$ in our study, which is similar to the study by Kasturi, et al. and as compared with other studies range from 4-25.4\% and PS affected in our study was $6.3 \%$ which is similar to study by Sharma et al. (Table 4). Ebstein anomaly was found in 9 cases (1.4\%) in our study, which is similar to study by (Kasturi et al.) where 1\% Ebstein anomaly found. TGA was found in 10 cases (1.5\%), which is somewhat lower than as compared to the study (Kinare et al., Sharma et 
al.) in which TGA was found in $12 \%$ and $22 \%$. Endocardial cushion defect was found in 8 cases (1.23\%), where in other studies by Kasturi et al., Jain KK et al., Bidwai et al., none of the cases of found.

The present findings indicate that CHDs in the present study in tertiary care center, Bhopal, MP. Central India is as high as the prevalence reported by other Indian studies by Shrestha et al., Gupta et al., Vashishta et al., Thakur et al., and it is a serious problem which requires immediate attention for the improvement of diagnostic and therapeutic facilities and echo is one of the best non-invasive tool for the diagnosis of congenital heart diseases and thus help in management of CHD.

\section{CONCLUSIONS}

The data in the present study suggests the distribution of congenital heart diseases at tertiary care center, Bhopal, MP, Central India. Congenital heart diseases were found in 648 of 10,000 cases undergoing echocardiography with VSD (30.5\%), ASD (23.6\%), PDA (9\%) are most common acyanotic congenital heart diseases and TOF $(8.4 \%)$ is the most common cyanotic congenital heart disease respectively. VSD is most prevalent in males and is highest among $0-5 y r s$. of age. Thus the echocardiography plays a major role in diagnosis of congenital heart diseases.

\section{REFERENCES}

1. Hoffman JI. Congenital heart disease: incidence and inheritance. Paediatrics Clin North Am 1990;37:25-43.

2. Melvin DC, William FA, Gerard PA, et al. ACC/AHA/ASE 2003 Guidelines Update for the Clinical Application of Echocardiography. A Report of the American College of Cardiology/American Heart Association Task Force on Practice Guidelines (ACC/AHA/ASE Committee to Update the 1997 Guidelines for the Clinical Application of Echocardiography). Circulation 2003;108:1146-1162.

3. Fyler DC, Buckley LP, Hellenbrand WE, et al. Report of the New England Regional Infant Care Program. Paediatrics 1980;65 suppl: 375-461.
4. Abdulla R. What is the prevalence of congenital heart diseases? Ped Cardiol 1997;18:268.

5. Chadha SL, Singh N, Shukla DK. Incidence of congenital heart diseases. Indian Journal of Paediatrics 2001;68:507-510.

6. Bidwai PS, Mahajan CM, Walia BNS, et al. Congenital heart disease in childhood. A Clinical Study 1971;691-94.

7. Jain KK, Sagar A, Beri S. Heart disease in children. Indian J Pediatr 1971;38:441-48.

8. Vashista VM, Kalra A, Kalra K, et al. Prevalence of congenital heart diseases in school children. Indian Journal of Paediatrics 1993;30:1337-1340.

9. Sharma M, Saxena A, Kothari S, et al. Profile of congenital heart disease: an echocardiographic study of 5000 consecutive children (Abstract). Indian Heart Journal 1996;48:521.

10. Andrej Robida, Gordon M Folger, et al. Incidence of congenital heart disease in Qatari Children. International Journal of Cardiology 1997;60:19-22.

11. Shresta NK, Padmavati S. Congenital heart disease in Delhi School Children. Indian J Med Res 1980;72:403407.

12. Gupta I, Gupta ML, Parihar A, et al. Epidemiology of rheumatic and congenital heart diseases in school children. J Indian Medical Assoc 1992;90:57-59.

13. Thakur JS, Negi PC, Ahluwalia SK, et al. Congenital heart disease among schoolchildren in Shimla hills. Indian Heart Journal 1995;47:232-235.

14. Kasturi L, Kulkarni AV, Amin A, et al. Congenital heart disease: clinical spectrum. Indian Pediatr 1999;36:953.

15. Kinare SG, Sharma S. Congenital heart disease in first year of life (An autopsy study of 270 cases). Indian Journal of Paediatrics 1981;48:745-754.

16. Khalil A, Aggarwal R, Thirupuram S, et al. Incidence of congenital heart disease among hospital live births in India. Indian Pediatr 1994;31:519-27. 